e-ISSN : 2621-4105

\title{
KEWENANGAN BAWASLU DALAM PENYELENGGARAAN PEMILU DI KOTA SEMARANG SUATU KAJIAN UNDANG- UNDANG NOMOR 7 TAHUN 2017 TENTANG PEMILU
}

\author{
Pulung Abiyasa \\ Magister Hukum, Universitas Semarang, Semarang \\ pulungabie@gmail.com
}

\begin{abstract}
Abstrak
Penelitian ini bertujuan untuk mengkaji dan menganalisa kewenangan Badan Pengawas Pemilu dalam penyelenggaraan pemilihan umum di kota Semarang. Kualitas pemilu salah satunya ditentukan oleh konsistensi Bawaslu dalam menjalankan tugas peran dan fungsinya. Kelahiran Bawaslu diharapkan dapat mendorong dan memperkuat pengawasan masyarakat dengan memberikan penguatan berupa regulasi, kewenangan, sumber daya manusia, anggaran, serta sarana dan prasarana. Berdasarkan Undang-Undang Nomor 7 Tahun 2017 tentang Pemilu, kedudukan Bawaslu semakin diperkuat dengan beberapa perubahan aturan antara lain yaitu penambahan jumlah anggota Bawaslu serta perluasan kewenangan Bawaslu.

Permasalahan yang dibahas dalam penelitian ini adalah bagaimana kewenangan Bawaslu dalam penyelenggaraan pemilu di Kota Semarang sesuai dengan UU Nomor 7 Tahun 2017 tentang Pemilu dan bagaimana kendala dan solusi Bawaslu dalam penyelenggaraan pemilu di Kota Semarang dalam tinjauan UU Nomor 7 Tahun 2017 tentang Pemilu. Hasil penelitian menunjukkan bahwa kewenangan Bawaslu dalam penyelenggaraan pemilu di Kota Semarang sesuai dengan UU Nomor 7 Tahun 2017 tentang Pemilu adalah sebagaimana diatur dalam Pasal 103. Kendala Bawaslu dalam penyelenggaraan pemilu di Kota Semarang dalam tinjauan UU Nomor 7 Tahun 2017 tentang Pemilu adalah kurangnya partisipasi dari masyarakat, adanya perbedaan persepsi/parameter dalam menyikapi pelanggaran pemilu, kurangnya komunikasi antara Bawaslu dengan KPU. Adapun solusi untuk mengatasinya adalah melakukan sosialisasi terhadap masyarakat dengan memberikan pengarahan dan dorongan terhadap masyarakat agar ikut serta dalam pengawasan pemilu, melakukan koordinasi pihak terkait supaya ada kesamaan menilai suatu kasus sehingga penegakan hukum bisa berjalan dengan baik, sebab kuncinya adalah adanya kordinasi dan komunikasi antara kedua lembaga, melakuan koordinasi dan komunikasi yang cukup intens dengan instansi terkait.
\end{abstract}

Kata kunci Kewenangan; Pengawasan; Pemilu 
e-ISSN : 2621-4105

\title{
BAWASLU AUTHORITY IN THE ADMINISTRATION OF THE ELECTIONS IN SEMARANG A STUDY ACT NUMBER 7 OF 2017 CONCERNING THE ELECTION
}

\author{
Pulung Abiyasa \\ Master of Law, Semarang University, Semarang \\ pulungabie@gmail.com
}

\begin{abstract}
This study aims to review and analyze the authority of the Election Supervisory Board in organizing general elections in the city of Semarang. The quality of elections, one of which is determined by the consistency of Bawaslu in carrying out the duties and functions. The birth of Bawaslu is expected to be able to encourage and strengthen community supervision by providing reinforcement in the form of regulations, authority, human resources, budget, and facilities and infrastructure. Based on Law No. 7 of 2017 concerning Elections, the position of the Election Supervisory Body is increasingly strengthened by several changes to the rules including the addition of the number of members of the Election Supervisory Body and expansion of the Election Supervisory Body authority. The problem discussed in this study is how the authority of the Election Supervisory Body in organizing elections in the City of Semarang is in accordance with Law Number 7 of 2017 concerning Elections and how are the obstacles and solutions of the Election Supervisory Body in organizing elections in the City of Semarang in the review of Law Number 7 of 2017 concerning Elections. The approach method in this research is sociolgois juridical, so the data used are primary data and secondary data. The data collection technique is carried out through field studies and literature studies while the data analysis technique uses qualitative analysis.The results showed that the authority of the Election Supervisory Body in organizing elections in the city of Semarang in accordance with Law Number 7 of 2017 concerning Elections is as stipulated in Article 103 The Constraints of the Election Supervisory Body in organizing elections in the City of Semarang in reviewing Law Number 7 of 2017 concerning Elections is the lack of participation from the public, there are differences in perceptions / parameters in responding to election violations, lack of communication between Bawaslu and KPU. The solution to overcome this is to socialize the community by giving direction and encouragement to the public to participate in election supervision, coordinating related parties so that there is a similarity in evaluating a case so that law enforcement can work well, because the key is the coordination and communication between the two institutions, carry out coordination and communication that is quite intense with relevant agencies.
\end{abstract}

Keywords: Authority; Supervisory; Election 
e-ISSN : 2621-4105

\section{A. PENDAHULUAN}

Di negara demokrasi, pemilu merupakan salah satu pilar dan mekanisme untuk mendapatkan pemimpin politik. Salah satu aspek penting dari rangkain proses pemilu adalah adanya pengawasan pelaksaan pemilu. Pasal 1 angka 7 Undang-Undang Nomor 7 Tahun 2017 tentang Pemilu mengatur tiga lembaga penyelenggara Pemilu, yaitu Komisi Pemilihan Umum (KPU), Badan Pengawas Pemilu (Bawaslu) dan Dewan Kehormatan Penyelenggara Pemilu (DKPP). Dari tiga lembaga tersebut, Bawaslu memiliki fungsi pengawasan pemilu. Hal ini sebagaimana diatur dalam Pasal 1 angka 17 Undang-Undang Nomor 7 Tahun 2017 yang menyatakan bahwa Bawaslu adalah lembaga penyelenggara pemilu yang mengawasi penyelenggaraan pemilu di seluruh wilayah Negara Kesatuan Republik Indonesia. Fungsi pengawasan ini menjadi sangat penting untuk menjaga agar proses penyelenggaraan pemilu tetap sesuai dengan asas dan prinsip penyelenggaraan Pemilu. ${ }^{1}$

Kualitas pemilu salah satunya ditentukan oleh konsistensi Bawaslu dalam menjalankan tugas peran dan fungsinya. Badan Pengawas Pemilu (Bawaslu) memiliki peran yang cukup penting dalam meningkatkan dan memaksimalkan kualitas dari penyelenggaraan pemilu yang memberikan kepastian terhadap tegaknya kedaulatan dan hak pilih dari masyarakat. ${ }^{2}$

Secara historis, kelahiran Bawaslu diharapkan dapat mendorong dan memperkuat pengawasan masyarakat dengan memberikan penguatan berupa regulasi, kewenangan, sumber daya manusia, anggaran, serta sarana dan prasarana. Bawaslu harus hadir menjadi solusi terhadap berbagai tuntutan untuk melakukan pengawasan dan penindakan atas berbagai pelanggaran pemilu yang dilakukan oleh siapa pun, termasuk kepada penyelenggara pemilu karena mereka tidak luput dari potensi melakukan pelanggaran. ${ }^{3}$

1 Sumardi, "Memperkuat Pengawasan Pemilu Serentak 2019, Sebuah Tantangan" (https://www.kompasiana.com, diakses 12 Mei 2019).

2 Angelo Emanuel Flavio Seac dan Sirajuddin, Penguatan Kewenangan Lembaga Badan Pengawas Pemilu Dalam Penegakan Hukum Pemilu, (http://www.publishing-widyagama.ac.id , diakses 12 Mei 2019).

3 Laksono Hari Wiwoho, "Peran Bawaslu dan Pemilu yang Berintegritas", (https://nasional.kompas.com, diakses 12 Mei 2019. 
Berdasarkan Undang-Undang Nomor 7 Tahun 2017 tentang Pemilu, kedudukan Bawaslu semakin diperkuat dengan beberapa perubahan aturan antara lain yaitu penambahan jumlah anggota Bawaslu serta perluasan kewenangan Bawaslu. Bawaslu memiliki kewenangan besar tidak hanya sebagai pengawas tetapi juga sekaligus sebagai eksekutor hakim pemutus perkara.

Pasal 99, Pasal 103, Pasal 106, Pasal 109, Pasal 112 Undang-Undang Nomor 7 Tahun 2017 tentang Pemilu menyatakan bahwa Bawaslu memiliki kewenangan sebagai berikut :

1. Menerima dan menindaklanjuti laporan yang berkaitan dengan dugaan pelanggaran pemilu;

2. Memeriksa dan mengkaji pelanggaran pemilu dan merekomendasikan pada pihak terkait

3. Menerima, memeriksa, memediasi atau mengadjudikasi, dan memutus penyelesaian sengketa proses pemilu

4. Merekomendasikan hasil pengawasan terhadap pelanggaran netralitas semua pihak yang dilarang ikut serta dalam kegiatan kampanye

5. Mengambil alih sementara tugas, wewenang dan kewajiban bawaslu ditingkat bawahnya

6. Meminta bahan keterangan yang kepada pihak dalam rangka pencegahan dan penindakan pelanggaran pemilu dan sengketa proses pemilu

Kewenangan Bawaslu sebagaimana diatur dalam Undang-Undang Nomor 7 Tahun 2017 tentang Pemilu tersebut di atas, dalam penanganan administratif dilakukan melalui proses yang terbuka, adjudikasi serta outputnya adalah produk putusan. Dari sisi hukum, kekuatan putusan dengan rekomendasi itu berbeda. Rekomendasi kekuatan eksekutorialnya agak lemah, sedangkan putusan, kekuatan eksekutorialnya jelas, apalagi dalam undang-undang disebutkan bahwa putusan bersifat final dan binding (mengikat). Penanganan pelanggaran bersifat Terstruktur Sistematis dan Masif (TSM), dalam Undang-Undang Nomor 7 Tahun 2017 tentang Pemilu semua jenis pelanggaran bisa masuk kualifikasi TSM, kalau 
memang memenuhi kualifikasi TSM. Penanganannya bisa dilakukan melalui ajudikasi dan dengan putusannya bisa mendiskualifikasi.

Mengingat bahwa tahun 2018 dan 2019 merupakan tahun pemilu dan dengan melihat sejarah pemilu Indonesia yang masih banyak terjadi pelanggaran tentunya peraturan baru tentang Bawaslu yang terdapat dalam UU No.7 Tahun 2017 akan mempengaruhi kinerja Bawaslu ke depannya yang diharapkan akan lebih baik jika dibandingkan dengan aturan sebelumnya. Saat ini dan ke depan, terbentang tantangan bagi Bawaslu untuk membuktikan peran dan eksistensi strategisnya mengawal pemilu yang berintegritas bagi kemajuan bangsa.

\section{B. PERMASALAHAN}

1. Bagaimana kewenangan Bawaslu dalam penyelenggaraan pemilu di kota Semarang menurut UU Nomor 7 Tahun 2017 tentang Pemilu?

2. Bagaimana kendala dan solusi Bawaslu dalam penyelenggaraan pemilu di Kota Semarang dalam tinjauan UU Nomor 7 Tahun 2017 tentang Pemilu?

\section{METODE PENELITIAN}

Untuk melakukan penelitian menggunakan metode pendekatan yuridis sosiologis.

Dengan demikian data yang digunakan adalah data primer dan data sekunder.

Teknik pengumpulan data dilakukan melalui studi kepustakaan dan wawancara sedangkan teknik analisis data menggunakan analisis kualitatif.

\section{PEMBAHASAN}

\section{Kewenangan Bawaslu Dalam Penyelenggaraan Pemilu di Kota Semarang Menurut UU Nomor 7 Tahun 2017 tentang Pemilu}

Penelitian ini menekankan pada kewenangan Bawaslu Kota Semarang dalam penyelenggaraan pemilu serentak tahun 2019 berdasarkan UU Nomor 7 Tahun 2017 tentang Pemilu. Menurut Arif Rahman, terkait kewenangan Bawaslu Kota Semarang diatur dalam Pasal 101 sampai dengan Pasal 104 Undang-Undang Nomor 7 Tahun 2017 tentang Pemilu. ${ }^{4}$

${ }^{4}$ Wawancara dengan Arif Rahman, Anggota Bawaslu Kota Semarang Bidang Koordinator Divisi Hukum, Data dan Informasi, (Semarang, 13 Agustus 2019). 
Kewenangan Bawaslu Kota Semarang dalam pelaksanaan tugas pengawasan dilaksanakan sejak sebelum penyelenggaraan pemilu sampai dengan adanya putusan hasil pemilu. Penjelasan dari Arif Rahman yang menyatakan bahwa sebelum pelaksnaaan pemilu, terdapat beberapa tahapan yang sangat panjang mulai dari pencalonan sampai dengan penetapan hasil pemilu. Misalnya untuk penentuan DPT (daftar pemilih tetap) dilaksanakan di awal dalam rentang waktu berbulan-bulan, bahkan sampai dengan pencoblosan masih ada DPT. Bawaslu Kota Semarang memiliki kewenangan untuk melakukan pengawasan dari awal sampai akhir proses penyelenggaran pemilu. ${ }^{5}$

Tahap kampanye pemilu, Bawaslu Bawaslu Kota Semarang berwenang untuk melakukan pengawasan. Sebagaimana diatur dalam Pasal 307 UndangUndang Nomor 7 Tahun 2017 tentang Pemilu yang menyatakan bahwa Bawaslu, Bawaslu Provinsi, Bawaslu Kabupaten/Kota, Panwaslu Kecamatan, Panwaslu Kelurahan/Desa, dan Panwaslu LN melakukan pengawasan atas pelaksanaan Kampanye Pemilu.

Kewenangan Bawaslu Kota Semarang dalam hal terjadi pelanggaran adalah sebagaimana diatur dalam Pasal 316 sampai dengan Pasal 318 UndangUndang Nomor 7 Tahun 2017 tentang Pemilu.

Berdasarkan ketentuan Undang-Undang Nomor 7 Tahun 2017 tentang Pemilu, pelanggaran pemilu meliputi pelanggaran kode etik, pelanggaran administrasi pemilu, pelanggaran peraturan perundang-undangan lain yang bukan sengketa Pemilu, dan bukan tindak pidana Pemilu. Berdasarkan ketentuan Pasal Pasal 460 Undang-Undang Nomor 7 Tahun 2017 tentang Pemilu pelanggaran administratif Pemilu meliputi pelanggaran terhadap tata cara, prosedur, atau mekanisme yang berkaitan dengan administrasi pelaksanaan Pemilu dalam setiap tahapan Penyelenggaraan Pemilu, yang tidak termasuk tindak pidana pemilu dan pelanggaran kode etik.

Cara penyelesaian pelanggaran administrasi pemilu adalah sebagaimana diatur dalam Pasal 461 Undang-Undang Nomor 7 Tahun 2017 tentang Pemilu.

${ }^{5}$ Wawancara dengan Arif Rahman, Anggota Bawaslu Kota Semarang Bidang Koordinator Divisi Hukum, Data dan Informasi, (Semarang, 13 Agustus 2019). 
Bawaslu selain memangani pelanggaran pemilu, juga juga berwenang menangani sengketa proses pemilu. Sengketa proses Pemilu menurut ketentuan Pasal 466 Undang-Undang Nomor 7 Tahun 2017 meliputi sengketa yang terjadi antar-Peserta Pemilu dan sengketa Peserta Pemilu dengan Penyelenggara Pemilu sebagai akibat dikeluarkannya keputusan KPU, keputusan KPU Provinsi, dan keputusan KPU Kabupaten/Kota.

Terkait dengan permohonan penyelesaian sengketa proses pemilu, diatur dalam Pasal 467 Undang-Undang Nomor7 Tahun 2017 tentang Pemilu.

Kewenangan Bawaslu selain menangani penyelesaian pelanggaran pemilu juga adalah menindaklanjuti adanya dugaan tindak pidana pemilu dengan memberikan rekomendasi terkait dugaan tindak pidana pemilu kepada Kepolisian. Hal ini sebagiamana diatur dalam Pasal 476 Undang-Undang Nomor7 Tahun 2017 tentang Pemilu.

Berdasarkan uraian diatas dapat diketahui bahwa kewenangan Bawaslu Kota Semarang dalam penyelenggaraan pemilu di Kota Semarang telah sesuai dengan UU Nomor 7 Tahun 2017 tentang Pemilu sebagaimana diatur dalam Pasal 103. Bawaslu telah menerima dan menindaklanjuti laporan yang berkaitan dengan dugaan pelanggaran pemilu, selanjutnya memeriksa dan mengkaji pelanggaran yang terjadi, untuk merekomendasikan hasil pemeriksaan dan pengkajiannya kepada pihak-pihak terkait, yaitu dalam hal pelanggaran administrasi rekomendasi ditujukan kepada KPU, pelanggaran kode etik terkait netralitas ASN/TNI rekomendasi ditujukan keapda KSN, sedangkan dalam hal tindak pidana pemilu direkomendasikan untuk penegakan hukum ke pihak kepolisian. Bawaslu juga telah meminta keterangan kepada pihak terkait KPU, pelapor dan terlapor dalam upaya pencegahan dan penindakan pelanggaran pemilu.

Ditinjau dari teori kewenengan sebagaimana dikemukakan oleh Philipus M. Hadjon, kewenangan Bawaslu dalam penyelenggaraan pemilu merupakan kewenangan atribusi. Kewenangan tersebut merupakan kewenangan yang diberikan oleh pembuat undang-undang sendiri kepada suatu organ pemerintahan, 
baik yang sudah ada maupun yang baru sama sekali. Bawaslu mengeluarkan putusan/rekomendasi terhadap pelanggaran pemilu berdasarkan ketentuan undang-undang yaitu Undang-Undang Nomor 7 Tahun 2017 tentang Pemilu.

Ditinjau dari teori kepastian hukum, dimana suatu peraturan dibuat dan diundangkan secara pasti karena mengatur secara jelas dan logis. Jelas dalam artian tidak terdapat kekaburan norma atau keraguan (multitafsir) dan logis dalam artian menjadi suatu sistem norma dengan asas-asas hukum dan norma lain sehingga tidak berbenturan atau menimbulkan konflik norma. Kepastian hukum menunjuk kepada pemberlakuan hukum yang jelas, tetap, konsisten dan konsekuen, yang pelaksanaannya tidak dapat dipengaruhi oleh keadaan-keadaan yang sifatnya subjektif.

Kepastian hukum juga merupakan tujuan dari setiap undang-undang. Kepastian hukum akan tercapai apabila kata dan kalimat undang-undang tersusun sedemikian jelasnya sehingga tidak menimbulkan penafsiran yang berbeda-beda. Kepastian hukum memiliki kaitan erat dengan penegakan hukum. Penegakan hukum itu sendiri merupakan suatu proses untuk mewujudkan keinginankeinginan hukum menjadi kenyataan. ${ }^{6}$

Kewenangan Bawaslu Kota Semarang dalam mengeluarkan rekomendasi terhadap pihak-pihak terkait didasarkan pada peraturan perundang-undangan yang sudah ada. Putusan Bawaslu Kota Semarang mengandung autotorif yaitu memberikan jalan keluar untuk menciptakan stabilitas rasa tertib dan ketentraman masyarakat. Proses penyelesaian pelanggaran pemilu, Bawaslu telah melakukan pengkajian maupun koordinasi denggan pihak-pihak terkait, sebelum akhirnya memberikan putsuan atau rekomendasi. Dalam UU Pemilu disebutkan bawha Putusan Bawaslu bersifat final, dan KPU juga diwajibkan untuk menindaklanjuti rekomendasi dari Bawaslu. hlm. 22 .

${ }^{6}$ Abdul Rachmad Budiono, Pengantar Ilmu Hukum, (Malang : Bayumedia Publishing, 2005), 


\section{Kendala dan Solusi Bawaslu dalam Penyelenggaraan Pemilu di Kota Semarang dalam Tinjauan UU Nomor 7 Tahun 2017 tentang Pemilu}

a. Kurangnya partisipasi dari masyarakat

Menurut Arif Rahman, terkait terkait efektivitas pengawasan perlu adnya partisipasi dari masyarakat, sehingga jangkauan wilayah Semarang yang luas bisa tercover dengan baik. Jangkauan wilayah yang luas, dan keterbatasan personil, maka untuk pengawasan diperlukan partisipasi dari masyarakat. Partisipasi masrakat ini yang didorong Bawaslu melalui kegiatan sosialisasi melalui kegiatan kampung anti politik uang di Tembalang. Yang ingin dibangun oleh Bawaslu adalah kesadaran masyarakat. ${ }^{7}$

Mengenai partisipasi masyarakat ini telah diatur dalam Pasal 102 ayat (1) huruf d UU Nomor 7 Tahun 2017 tentang Pemilu yang menyatakan bahwa dalam dalam melakukan pencegahan pelanggaran Pemilu dan pencegahan sengketa proses Pemilu sebagaimana dimaksud dalam Pasa1101 huruf a, Bawaslu Kabupaten/Kota bertugas meningkatkan partisipasi masyarakat dalam pengawasan Pemilu.

Namun masih banyak masyarakat yang bersikap pasif dengan kegiatan Bawaslu tersebut. Tidak semua masyarakat memiliki kesadaran hukum tinggi, sehingga praktik politik uang masih marak terjadi dan tidak ada yang berusaha untuk melaporkan ke Bawaslu.

Solusi untuk mengatasi hal tersebut adalah dengan melakukan sosialisasi terhadap masyarakat dengan memberikan pengarahan dan dorongan terhadap masyarakat agar ikut serta dalam pengawasan pemilu.

b. Adanya perbedaan persepsi/ parameter dalam menyikapi pelanggaran pemilu

Berdasarkan wawancara dengan Rahman, terkadang dalam menilai suatu pelanggaran terdapat perbedaan antara Bawaslu dengan kepolisian dan kejaksaan. Misalnya pada pemilu 2019, terdapat 4 kasus yang diputus second opinion/beda pendapat. Menurut Bawaslu kasus tersebut sudah memenuhi unsur-unsur materiil terjadi tindak pidana pemilu dan bisa ditingatkan ke tahap

7 Wawancara dengan Arif Rahman, Anggota Bawaslu Kota Semarang Bidang Koordinator Divisi Hukum, Data dan Informasi, (Semarang, 13 Agustus 2019) 
penyidikan, tapi kepolisian dan kejaksaan berpendapat lain. Sebagai contoh pada kasus di Kecamatan Semarang Selatan yang menurut Bawaslu sudah termasuk tindak pencurian/manipulasi data. Sesuatu yang sudah ditetapkan dan diputuskan di rapat pleno hasilnya diubah secara sepihak setelah selesai direkap. Artinya hasil rekap sudah diputus hasilnya sekian, tapi karena persoalan teknis, maka fotokopi dan print dilakukan di luar. Karena kejadian sudah malam, maka diputuskan hardcopy diserahkan pagi. Diantara rentang waktu tersebut terjadi praktik manipulasi data dengan mengubah angka hasil rekap. Atas peristiwa tersebut, caleg yang dirugikan melaporkan ke Bawaslu disertai bukti. Akrhinya Bawaslu mengumpulkan jajaran untuk mengumpulkan data dan memang ada ada manipulasi (pencurian) data, karena mengubah suara calon tertentu dan memasukkan ke calon suara tertentu. Mengambil suara parpol untuk dimasukkan ke calon tertentu. Tindakan Bawaslu adalah yang pertama, menyangkut pelanggaran adminstrasi, akan disampaikan dalam proses rekap tingkat kota, dan yang kedua ada praktik mengarah ke tindak pidana pemilu (mengubah, mengganti) angka. ${ }^{8}$

Solusi untuk mengatasi hal itu adalah Bawaslu itu pada saat rekap perolehan suara ke kota menyampaikan keberatan terkait dengan adanya hasil yang ditetapkan, karena KPU hanya merujuk hasil yang ditetapkan kecamatan, padahal ternyata salah satu kecamatan ada praktik manipulasi. Setelah menyampaikan kerberatan, rekomendasi dilakukan pengecekan kembali dokumen yang ada, kalau ada perbedaan hasil supaya dikembalikan sesuai dokumen yang ada. Tidak butuh suara, hanya dokumen rekap tingkat kecmatan/kelurahan. Jadi rekapitulasinya itu yang dicek kembali. Atas hal ini, akhirnya posisi yang dirugikan kembali sepereti semula sesuai dengan perhitungan pemilu itu sendiri.

Penjelasan yang senada juga disampaikan oleh Joko Purnomo yang menyatakan bahwa terkadang muncul perbedaan persepsi/ parameter antara KPU dengan Bawaslu. Misalnya Bawaslu merekomendasikan ke KPU untuk

8 Wawancara dengan Bapak Arif Rahman, Anggota Bawaslu Kota Semarang Bidang Koordinator Divisi Hukum, Data dan Informasi, (Semarang, 13 Agustus 2019) 
dilakukan pemungutan suara ulang, tapi ternyata setelah dilakukan pengkajian dan penyelidikan oleh KPU tidak sampai harus dilakukan pemungutan suara ulang. ${ }^{9}$

Solusi untuk mengatasi hal tersebut adalah melakukan koordinasi dengan Bawaslu secara instens supaya ada kesamaan menilai suatu kasus sehingga penegakan hukum bisa berjalan dengan baik, sebab kuncinya adalah adanya kordinasi dan komunikasi antara kedua lembaga. ${ }^{10}$

c. Kurangnya komunikasi antara Bawaslu dengan KPU

Menurut Joko Purnomo, Bawaslu dalam proses pengawasannya menyasar badan penyelenggara yaitu KPU. Artinya Bawaslu kota bisa mengawasi apa yg dilakukan KPU Kota, tetapi KPU Kota tidak bisa mengawasi Bawaslu Kota. Hal ini yang kemudian menjadikan kurangnya komunikasi antara Bawaslu dengan KPU. ${ }^{11}$

Solusi untuk mengatasi kendala tersebut adalah dengan melakuan koordinasi dan komunikasi yang cukup intens. Perlunya koordinasi dengan Bawaslu ada yang sifanya insidental, maupun koordinasi rutin baik melalui pertemuan secara langsung maupun melalui surat menyurat.

\section{E. PENUTUP}

Kewenangan Bawaslu dalam penyelenggaraan pemilu di Kota Semarang sesuai dengan UU Nomor 7 Tahun 2017 tentang Pemilu adalah sebagaimana diatur dalam Pasal 103 yaitu menerima dan menindaklanjuti laporan, memeriksa, mengkaji dugaan pelanggaran pemilu serta merekomendasikan ke pihak terkait; menerima, memeriksa, memediasi atau mengadjudikasi, dan memutus penyelesaian sengketa proses Pemilu di wilayah kota; merekomendasikan kepada instansi yang bersangkutan mengenai hasil pengawasan terhadap netralitas semua pihak yang dilarang ikut serta dalam kegiatan kampanye; meminta bahan

\footnotetext{
${ }^{9}$ Wawancara dengan Bapak Joko Purnomo, Mantan Ketua KPU Jateng 2013-2018, (Semarang, 20 Agutus 2019)

${ }^{10}$ Wawancara dengan Bapak Joko Purnomo, Mantan Ketua KPU Jateng 2013-2018, (Semarang, 20 Agutus 2019)

${ }^{11}$ Wawancara dengan Bapak Joko Purnomo, Mantan Ketua KPU Jateng 2013-2018, (Semarang, 20 Agutus 2019)
} 
keterangan yang dibutuhkan kepada pihak terkait dalam rangka pencegahan dan penindakan pelanggaran Pemilu dan sengketa proses pemilu di wilayah Kota Semarang. Kendala Bawaslu dalam penyelenggaraan pemilu di Kota Semarang dalam tinjauan UU Nomor 7 Tahun 2017 tentang Pemilu adalah kurangnya partisipasi dari masyarakat, adanya perbedaan persepsi/parameter dalam menyikapi pelanggaran pemilu, kurangnya komunikasi antara Bawaslu dengan KPU. Adapun solusi untuk mengatasinya adalah melakukan sosialisasi terhadap masyarakat dengan memberikan pengarahan dan dorongan terhadap masyarakat agar ikut serta dalam pengawasan pemilu, melakukan koordinasi pihak terkait supaya ada kesamaan menilai suatu kasus sehingga penegakan hukum bisa berjalan dengan baik, sebab kuncinya adalah adanya kordinasi dan komunikasi antara kedua lembaga, melakuan koordinasi dan komunikasi yang cukup intens dengan instansi terkait. 
e-ISSN : 2621-4105

\section{DAFTAR PUSTAKA}

\section{Buku}

Budiono, Abdul Rachmad, 2005, Pengantar Ilmu Hukum, Malang : Bayumedia Publishing.

Angelo Emanuel Flavio Seac dan Sirajuddin, Penguatan Kewenangan Lembaga Badan Pengawas Pemilu Dalam Penegakan Hukum Pemilu, (http://www.publishingwidyagama.ac.id, diakses 12 Mei 2019).

Laksono Hari Wiwoho, "Peran Bawaslu dan Pemilu yang Berintegritas", (https://nasional.kompas.com, diakses 12 Mei 2019.

Sumardi, "Memperkuat Pengawasan Pemilu Serentak 2019, Sebuah Tantangan" (https://www.kompasiana.com, diakses 12 Mei 2019).

\section{Peraturan perundang-undangan}

Undang-Undang Dasar Negara Republik Indonesia Tahun 1945.

Undang-Undang Nomor 7 Tahun 2017 tentang Pemilu

Peraturan Pemerintah Nomor 82 Tahun 2012 tentang Penyelenggaraan Sistem dan Transaksi Elektronik. 